\title{
Drying and soaking pretreatments affect germination in pedunculate oak
}

\author{
Colin N. Doody, Conor O’REILLY* \\ School of Biology and Environmental Science, University College Dublin, Belfield, Dublin 4, Ireland
}

(Received 9 September 2007; accepted 2 April 2008)

\begin{abstract}
-
- Pedunculate oak (Quercus robur L.) acorns are recalcitrant so they are difficult to store. Therefore, deterioration in quality during storage may reduce seedling yield and quality. In an attempt to address this, the effects of drying and soaking treatments on acorn germination were assessed.

- After harvesting on two occasions in October, the moisture content (MC) of acorns were adjusted using the following treatments: (1) fresh state or control (46-48\% MC); (2) soaked in fresh state (46-48\%); (3) dried (40-42\%) (standard method); and (4) dried and then soaked (46-48\%). The treated acorns were allowed to germinate at $15{ }^{\circ} \mathrm{C}$, both before and after storage at $-3{ }^{\circ} \mathrm{C}$.

- Treatment effects were generally consistent for each harvest date. Compared to the untreated controls, soaking alone and drying followed by soaking significantly increased germination both before and after storage. Storage reduced germination, except for the dried and soaked acorns.

- The results confirmed that drying and soaking improved acorn germination, but this was not mediated through an effect on acorn MC. In a separate nursery experiment, acorns given this treatment resulted in higher seedling yields and better quality plants than those given the standard treatment (dried to $40-42 \% \mathrm{MC})$.
\end{abstract}

Quercus robur / pretreatment / storage / harvest date

Résumé - Séchage et trempage, des prétraitements qui influencent la germination du chêne pédonculé.

- Les glands du chêne pédonculé (Quercus robur L.) sont difficiles à stocker. En conséquence, la détérioration de leur qualité pendant le stockage peut réduire la production et la qualité des semis. Pour répondre à ceci, les effets de prétraitements de séchage et de trempage sur la germination des glands ont été évalués.

- Après récolte à deux occasions en octobre, la teneur en eau (MC) des glands a été ajustée en utilisant les traitements suivants : (1) état frais ou témoin (46-48\% MC), (2) trempage à l'état frais (46-48\% MC), (3) séché (40-42\% MC) (méthode standard), (4) séché puis trempé (46-48 \% MC). Les traitements permirent une germination des glands à $15^{\circ} \mathrm{C}$, aussi bien avant qu'après un stockage à $-3^{\circ} \mathrm{C}$.

- Les effets des traitements furent en général cohérents pour chaque date de récolte. Comparés aux traitements témoins, le trempage seul et le séchage suivi par un trempage ont accru significativement la germination aussi bien avant qu'après stockage. Le stockage réduit la germination sauf dans le cas des glands séchés et trempés.

- Les résultats confirment que le séchage et le trempage améliorent la germination des glands, mais ceci n'est pas obtenu par l'intermédiaire d'un effet sur la teneur en eau des glands. Dans une expérimentation séparée en pépinière, ces traitements entraînent une plus grande production de semis et une meilleure qualité des plants que ceux issus du traitement standard (séché à 40-42\% MC).

Quercus robur / prétraitements / stockage / date de récolte

\section{INTRODUCTION}

The seed ${ }^{1}$ of pedunculate oak (Quercus robur L) are "recalcitrant", which means that they are intolerant of desiccation and cannot be stored over more than about one winter without loss of seed viability (Gordon, 1992). Therefore, pre-treatment and storage protocols that enhance germination and maintain viability of acorns are of interest to nurseries.

* Corresponding author: conor.oreilly@ucd.ie

${ }^{1}$ The one seeded (occasionally two seeded) fruit of the oak is the acorn (Bonner and Vozzo, 1987), but for convenience the terms 'acorn' and 'seed' will be used interchangeably in this paper.
Seeds of the white oak group, of which pedunculate oak is a member, mature within one year (Suszka et al., 1996). Acorns increase steadily in size as they mature and their colour changes from green to brown during this process. Abscisic acid (ABA) concentrations also change during maturation (Finch-Savage and Clay, 1994). Acorns also lose water during maturation, with the most rapid decline occurring towards the end of maturation (Bonner and Vozzo, 1987). Therefore, acorn maturity and moisture content (MC) at the time of harvesting may influence acorn storability.

While the seed of 'orthodox' species can be stored for years if dried to low MC, oak acorns cannot be dried to a low MC without losing viability (Gordon, 1992). Acorns are usually 
Table I. Physical and germination characteristics of the seed lots of the acorns used in the study.

\begin{tabular}{|c|c|c|c|c|c|c|c|}
\hline Seed identity & Country & Provenance & $\begin{array}{l}\text { Seed } \\
\text { Year }\end{array}$ & $\begin{array}{l}\mathrm{MC} \\
(\%)\end{array}$ & $\begin{array}{l}\text { Seed } \\
\text { per } \mathrm{kg}\end{array}$ & $\begin{array}{l}\text { Viable seeds } \\
\text { per } \mathrm{kg}\end{array}$ & $\begin{array}{l}\text { Germination } \\
\%\end{array}$ \\
\hline & & \multicolumn{6}{|c|}{ Experiment 1. Laboratory tests } \\
\hline OP-IEOYC-GO7 & Ireland & Charleville, Co. Offaly & 2006 & 46 & 274 & 213 & 97.0 \\
\hline OP-NLNU-E50 & The Netherlands & Nuenen 01 & 2004 & 38 & 256 & 197 & 74.0 \\
\hline OP-NLTU-F21 & The Netherlands & Nuenen 01 & 2005 & 42 & 237 & 203 & 85.5 \\
\hline
\end{tabular}

shed at MC of 48-53\% (Bonner and Vozzo, 1987) and are usually dried back to 40-45\% MC before storage (Gordon, 1992), mostly to help reduce fungal growth (Aldhous and Mason, 1994). Acorn viability begins to decline if MC is reduced below about 40\% (Poulsen, 1992); this is often considered the critical MC for acorn viability (Gosling, 1989; Suszka and Tylkowski, 1980).

Since pedunculate oak seeds have to be stored at high (> 40\%) MC to maintain viability, premature radicle emergence can be expected, particularly during storage at temperatures above freezing. Suszka and Tylkowski (1980) found that radicle emergence in pedunculate oak acorns did not occur during storage at $-1{ }^{\circ} \mathrm{C}$ over one winter. It has been suggested that acorns of some species of the white oak group have only a weak epicotyl dormancy (Bonner and Vozzo, 1987) while others have suggested that the emergence of the radicle is restricted by the pericarp (mechanical dormancy) (Poulsen, 1992), chemical inhibitors in the pericarp or possibly other factors (Bonner and Vozzo, 1987). Jensen (2002) suggested that storage at 3 to $5{ }^{\circ} \mathrm{C}$ was necessary to break this epicotyl dormancy. However, Özbingöl and O'Reilly (2005) and Suszka and Tylkowski (1980) found that acorns germinated well after storage at freezing temperatures (down to $-3{ }^{\circ} \mathrm{C}$ ) suggesting that freezing might also help to overcome dormancy. In fact, Özbingöl and O'Reilly (2005) found that acorns had higher germination after 4 months than after 2 months storage at $-3{ }^{\circ} \mathrm{C}$.

The standard method, used operationally in Ireland and elsewhere in much of Europe, is to dry pedunculate oak acorns to about 40-42\% MC for storage (Gordon, 1992). However, Özbingöl and O'Reilly (2005) demonstrated that soaking acorns that had previously been dried for storage improved laboratory germination, but it was unclear if the beneficial effect of soaking was a result of increasing acorn MC or other effects. In addition, it was unknown if acorns that were harvested at high initial MC (i.e. not dried back) would have high germination potential. Therefore, four seed pretreatment methods were used in this study to determine which factor improved germination. Since acorns lose water during maturation, the response may vary with maturity state and $\mathrm{MC}$ at the time of harvesting. Harvest date may also have implications for nursery operations. If high $\mathrm{MC}$ is the main factor improving poststorage germination, it may be feasible to harvest the acorns when MC is high, thus avoiding the need for soaking. The main aim of this study was to determine if soaking improved germination through acorn MC effects or through other means and to evaluate the effect of harvest date on this response.

Although Özbingöl and O'Reilly (2005) showed that soaking acorns that previously had been dried back increased post-storage germination in laboratory tests, no information is available on the potential effect of this treatment on seedling emergence and plant growth in the nursery. A second objective of this study was to evaluate in the nursery the effect of soaking acorns prior to freezing storage (compared to the standard method) on germination and the growth and quality of plants derived from these acorns.

\section{MATERIALS AND METHODS}

\subsection{Seed material}

Two separate experiments, a laboratory (experiment 1) and a field experiment (experiment 2), were conducted using seedlots supplied by Coillte Seed Centre (Co. Carlow, Ireland) (Tab. I). In experiment 1 , the acorns were harvested from a seed stand in Charleville, Co. Offaly on two separate occasions in mid and late October 2006. The acorns were harvested specifically for this experiment and were delivered to University College Dublin (UCD) in a 'fresh' state (MC 46-48\%) about $24 \mathrm{~h}$ after harvesting. In experiment 2, one seedlot originating in the Netherlands was used each year (Tab. I). The acorns were handled, processed and stored following standard operational procedures; this involved drying them back to about $40-42 \% \mathrm{MC}$. The date of harvesting is not known, but the acorns arrived at the Seed Centre in early November each year. The acorns were treated and then stored at $-3{ }^{\circ} \mathrm{C}$ at Ballintemple Nursery, Co. Carlow (see below).

\subsection{Experiment 1: Seed treatment and storage effects on laboratory germination}

\subsubsection{Soaking, drying and storage treatments}

The effects of drying and soaking treatments on percentage germination and mean germination time (MGT) after 0 and 6 months storage were assessed. The acorns were held at $-3{ }^{\circ} \mathrm{C}$ at UCD until the treatments commenced.

The following treatment combinations were applied:

(1) Fresh state or control (no soaking or drying), 46-48\% MC;

(2) Soaked in fresh state, $46-48 \% \mathrm{MC}$;

(3) Dried, 40-42\% MC (standard method);

(4) Dried (40 to $42 \% \mathrm{MC}$ ) and then soaked, 46-48\% MC. 
Unless otherwise stated, acorns were held at $3{ }^{\circ} \mathrm{C}$ until all treatments had been completed. The acorns were soaked for 5 days in cold water ( 3 water: 1 seeds; vol:vol) at $3{ }^{\circ} \mathrm{C}$. The water was changed once daily during this period. The results of previous experiments have shown that this period is sufficient to fully imbibe acorns (Özbingöl and O'Reilly, 2005). After soaking, the acorns were placed on plastic trays and surface dried with paper towels. The MC of the acorns was determined, based on four samples of five acorns (each cut into four pieces), after drying them at $105^{\circ} \mathrm{C}$ for $24 \mathrm{~h}$. The $\mathrm{MC}$ of the freshly harvested acorns at the end of the soaking period was 46-48\%, similar to their initial MC. Other acorns (that were not soaked) were dried back to approximately 40-42\% MC (standard method used operationally) over an 18 -h period at room temperature $\left(20-22{ }^{\circ} \mathrm{C}\right)$ in the laboratory. After treatment, all acorns were placed in plastic bags $(30.5 \times 46.5 \mathrm{~cm}, 500$ Gauge, The Packaging Centre, Naas Road, Dublin 22, Ireland) that had been manually perforated (approximately one perforation per $2 \mathrm{~cm}^{2}$ ) and then stored at $-3{ }^{\circ} \mathrm{C}$ (approx $-2.5^{\circ} \mathrm{C}$ at centre of storage bags). The $\mathrm{MC}$ was tested after storage and was approximately the same as the initial MC.

\subsubsection{Germination tests}

Each treatment combination was represented by four replications of 25 seeds each. The seeds were placed on cotton wool moistened with distilled water in rectangular plastic germination boxes $(17 \times 10.5 \times 6 \mathrm{~cm})($ Hofstatter \& Ebbesen A/S, Espergaerde, Denmark). The boxes were placed in incubators (CMC germination cabinet, 4001, D/L, Glesborg, Denmark) at $15{ }^{\circ} \mathrm{C}$ with $8 \mathrm{~h}$ of lighting per day. The number of seeds that germinated (radicle $>1 \mathrm{~cm} \mathrm{long}$ ) was recorded twice weekly for 60 days. Acorns that had not germinated during the 60-day period were placed on trays of moist peat at room temperature $\left(20-22{ }^{\circ} \mathrm{C}\right)$ and allowed to germinate for another 30 days. However, few acorns germinated during the additional test period. MGT was calculated as the mean number of days for acorns to germinate during the 60-day incubation period (Jones and Gosling, 1994). For example, for seeds evaluated on days 0,4 and 9, the MGT formula would be: ((number counted day $0 \times 0)+($ number counted day $4 \times(0+4 / 2))+($ number counted day $9 \times(4+9 / 2)))$.

\subsection{Experiment 2: seedling emergence and growth in nursery}

\subsubsection{Site, treatments, experimental design and sowing}

The effect of two different seed pretreatments on seedling emergence and subsequent seedling growth was evaluated. The response of acorns that received the standard (acorns dried to $<42 \% \mathrm{MC}$ before arrival at nursery) treatment versus those that were given the drying and soaking treatment combination (acorn MC 46-48\%) (the same as the DS treatment, experiment 1) was studied. The acorns were treated in November, a few days after their arrival at the nursery. Acorns of both treatment groups were stored in bags (as in experiment 1 ) at $-3{ }^{\circ} \mathrm{C}$ at the nursery until the time of sowing the following year.

The experiment was carried out at Coillte Nursery, Ballintemple, Co. Carlow, Ireland (52 44' N, 6' W, $100 \mathrm{~m}$ a. s. 1.). The soil in the nursery is a sandy loam ( $\mathrm{pH} 5.5)$ with an organic matter content of $6-8 \%$ and silt, sand and clay fractions of 66,19 and $15 \%$, respectively.
The 2005 experiment was a randomised split-plot design. Two adjacent seed beds (main plots) were randomly assigned for sowing in March or April. Each main plot was divided into four blocks, each block containing one 6-m sub-plot of each seed treatment. In 2006, the acorns were sown in three beds (blocks), each bed containing three 2-m plots (replications) of each seed treatment. The treatments were randomly assigned to plots within each block each year.

Since the DS acorns had higher germination in the laboratory tests, they were sown at lower rates than the standard (dried) ones with the objective of achieving similar plant densities in all plots. In 2005 , the acorns were sown at $1 \mathrm{~kg} \mathrm{~m}^{-2}$, which is equivalent to about 256 acorns per $\mathrm{m}^{2}$ for the dried (standard) acorns and 226 for the DS acorns. Since the acorns were sown by machine in 2005, there was some variability in the actual numbers sown per $\mathrm{m}^{2}$. Therefore in 2006 , the acorns were hand-sown at exactly 200 per $\mathrm{m}^{2}$ for the standard-treated acorns and 175 per $\mathrm{m}^{2}$ for the DS acorns, which was equivalent to approx. $0.840 \mathrm{~kg} \mathrm{~m}^{-2}$ in both treatments. Similar to the machine method used in 2005, the seeds were sown in lines and covered with about $4 \mathrm{~cm}$ of soil. Soon after sowing, nylon mesh nets were erected over the beds, supported by wire hoops, to protect the seeds from predation.

\subsubsection{Observations and measurements}

Four 1-m long sampling points, approximately $0.5 \mathrm{~m}$ apart from each other, excluding the first and last $0.5 \mathrm{~m}$, were located in each sub-plot in 2005. The total number of seedlings was recorded in November at each location. The results of previous experiments in oak (data on file) showed that the number of seedlings counted at the end of the growing season (including any dead plants) was almost identical to seedling emergence values determined in the spring after germination had ceased. The total number of plants per sampling point and the height and root collar diameter of 10 plants at the centre of the bed at each sampling location were determined. Some seedlings were also dispatched to UCD for further study. Five plants from each side of the centre of the second and fourth sampling points in each sub-plot were lifted and dispatched. The height and diameter of each seedling was measured, after which the root and shoot was excised at the root collar. The shoots and roots were dried separately at $105{ }^{\circ} \mathrm{C}$ for $24 \mathrm{~h}$.

The approach used in 2006 was similar to 2005, but more data were collected. The number of seedlings that had emerged was counted at weekly intervals from 17 th June until emergence had ceased, in late July. Since a large proportion of the plants had emerged by the first date, speed of emergence was determined based upon these values. The number of plants that had emerged in a plot was expressed as a percentage of total emergence in that plot. Treatment differences in total germination do not affect germination speed using this approach. Final emergence was also calculated, based upon the total number of seedlings counted, as a percentage of the number of acorns sown per plot. The morphological characteristics of the seedlings were assessed in November 2006. The number of seedlings per plot and the diameter and height of 20 seedlings in the centre of the plot were determined. The proportion of seedlings that exceeded $20 \mathrm{~cm}$ height (lower than current nursery benchmark of $40 \mathrm{~cm}$ ) was calculated from these data. The same 20 seedlings were lifted in March 2007 and then dispatched to UCD to assess dry weights using the same protocols described above for 2005.

In the 2006 experiment, an additional 10 seedlings were lifted in March 2007 from an immediately adjacent location in the bed 
Table II. ANOVA of the effect of collection date, storage, drying and soaking on percentage germination and MGT of oak seeds. $P$ values $<$ 0.05 are in bold.

\begin{tabular}{|c|c|c|c|c|c|c|c|c|}
\hline \multirow[t]{2}{*}{ Source } & \multicolumn{3}{|c|}{ Germination } & \multirow[b]{2}{*}{$P$} & \multicolumn{4}{|c|}{ MGT } \\
\hline & $\mathrm{df}$ & $M S \times 10^{3}$ & $F$ & & $\mathrm{df}$ & $M S$ & $F$ & $P$ \\
\hline Harvest date $(\mathrm{H})$ & 1 & 0.564530 & 2.16 & 0.1483 & 1 & 51.7 & 4.34 & 0.0426 \\
\hline Drying (D) & 1 & 2.719668 & 10.40 & 0.0023 & 1 & 0.1 & 0.04 & 0.8374 \\
\hline Soaking (S) & 1 & 3.431792 & 13.12 & 0.0007 & 1 & 1089.4 & 91.37 & $<0.0001$ \\
\hline Storage (St) & 1 & 2.873399 & 10.99 & 0.0018 & 1 & 546.2 & 45.82 & $<0.0001$ \\
\hline $\mathrm{H} \times \mathrm{D}$ & 1 & 0.085864 & 0.33 & 0.5693 & 1 & 12.7 & 1.07 & 0.3069 \\
\hline $\mathrm{H} \times \mathrm{S}$ & 1 & 2.136709 & 8.17 & 0.0063 & 1 & 68.8 & 5.77 & 0.0202 \\
\hline $\mathrm{H} \times \mathrm{St}$ & 1 & 0.267466 & 1.02 & 0.3169 & 1 & 116.6 & 9.78 & 0.0030 \\
\hline $\mathrm{D} \times \mathrm{S}$ & 1 & 0.392945 & 1.50 & 0.2262 & 1 & 27.5 & 2.31 & 0.1350 \\
\hline $\mathrm{D} \times \mathrm{St}$ & 1 & 0.553816 & 2.12 & 0.1521 & 1 & 72.6 & 6.09 & 0.0172 \\
\hline $\mathrm{S} \times \mathrm{St}$ & 1 & 0.634417 & 2.43 & 0.1259 & 1 & 0.7 & 0.05 & 0.8160 \\
\hline $\mathrm{H} \times \mathrm{D} \times \mathrm{S}$ & 1 & 0.518452 & 1.98 & 0.1656 & 1 & 16.0 & 1.34 & 0.2520 \\
\hline $\mathrm{H} \times \mathrm{S} \times \mathrm{St}$ & 1 & 0.482244 & 1.84 & 0.1808 & 1 & 23.8 & 2.00 & 0.1641 \\
\hline $\mathrm{D} \times \mathrm{S} \times \mathrm{St}$ & 1 & 1.340025 & 5.12 & 0.0282 & 1 & 62.6 & 5.25 & 0.0264 \\
\hline Error & 48 & 0.261501 & & & 48 & 11.9 & & \\
\hline
\end{tabular}

to that used in previous sampling to assess root growth potential (RGP). RGP, which is the ability of seedlings to initiate new roots in a favourable growing environment, is an important plant quality attribute (Ritchie, 1984). The lifted seedlings were bulked by treatment and block, for a total of six bundles (two treatments $\times$ three blocks) and then dispatched to UCD.

The seedlings were planted in $3.5 \mathrm{~L}$ pots (replicates) containing a mixture (3:1; vol:vol) of peat and perlite. Each of the 30 pots per treatment contained three seedlings, one seedling from each nursery block. The seedlings were allowed to grow for six weeks in an unheated greenhouse (temperature approx. $15-20{ }^{\circ} \mathrm{C}$ during the day, $8-10{ }^{\circ} \mathrm{C}$ at night) and were watered every four or five days. At the end of the test, the seedlings were removed from the pots and the roots washed in tap water. The number of new white roots greater than $1 \mathrm{~cm}$ long was counted.

\subsection{Data analyses}

The laboratory data were analysed according to a full factorial ANOVA design to test for the effects of harvest date, storage duration, soaking, drying and their interactions on percentage germination per box and MGT using the GLM procedure in SAS (SAS Inc, 1989). All effects in the model were considered fixed. Percentage data were transformed to arc-sine square root values. Means were compared further using least significant means tests.

The 2005 nursery data were analysed according to a randomised block, split-plot ANOVA design to test for the effects of block, sowing date, treatment and the interaction between sowing date and treatment on emergence and seedling morphology. Sowing date effects were tested using the interaction of sowing date by treatment as an error term. Although the acorns were sown by weight only in 2005, these values were converted to percentages based on the number of acorns per kg (determined before sowing so that they reflected the effect of seed MC on number per $\mathrm{kg}$ in each treatment group). This adjustment was done to facilitate comparison of data between years. Since small hand-sown plots were used in 2006, the actual number of acorns sown per plot was recorded and the data were analysed according to a fully randomised ANOVA block design to test for the effects of block and treatment on emergence, speed of emergence and morphology. A $t$-test was used to test for treatment effects on RGP.

\section{RESULTS}

\subsection{Experiment 1: Seed treatment and storage effects on laboratory germination}

\subsubsection{Germination}

Soaking significantly increased percentage germination (Tab. II). The main effect of drying on germination was small, but it had a large effect in combination with other treatments. Storage significantly reduced germination, but the magnitude of this response varied with treatment. The main effect of harvest date was not significant, but it was significant in combination with soaking and storage treatments. The acorns that had been harvested on the second date, which were dried and soaked, had the highest germination (ca. 80\%) both before and after storage (Fig. 1).

For the acorns that were not stored, soaking increased germination to $79 \%$ compared with $71 \%$ for the untreated controls for acorns harvested on the first date, and to $77 \%$ compared to $70 \%$ for the controls for those harvested on the second date.

The effect of drying was largest for the stored acorns (Fig. 1). After storage for example, acorns harvested on first date that had been dried $(74 \%)$ or dried and soaked $(75 \%)$ had higher germination than the controls $(69 \%)$. The equivalent values for acorns harvested on the second date were $68 \%, 80 \%$ and $71 \%$ for the dried, the dried and soaked and the controls, respectively.

Although the non-stored acorns had a higher germination than those stored for six months, the effect of storage varied greatly with the drying and soaking treatment. Germination after storage of acorns harvested on the first date decreased significantly from $79 \%$ to $69 \%$ for those that were soaked but not dried (Fig. 1). However, storage had no significant effect on the germination of acorns that were dried and soaked before storage. 


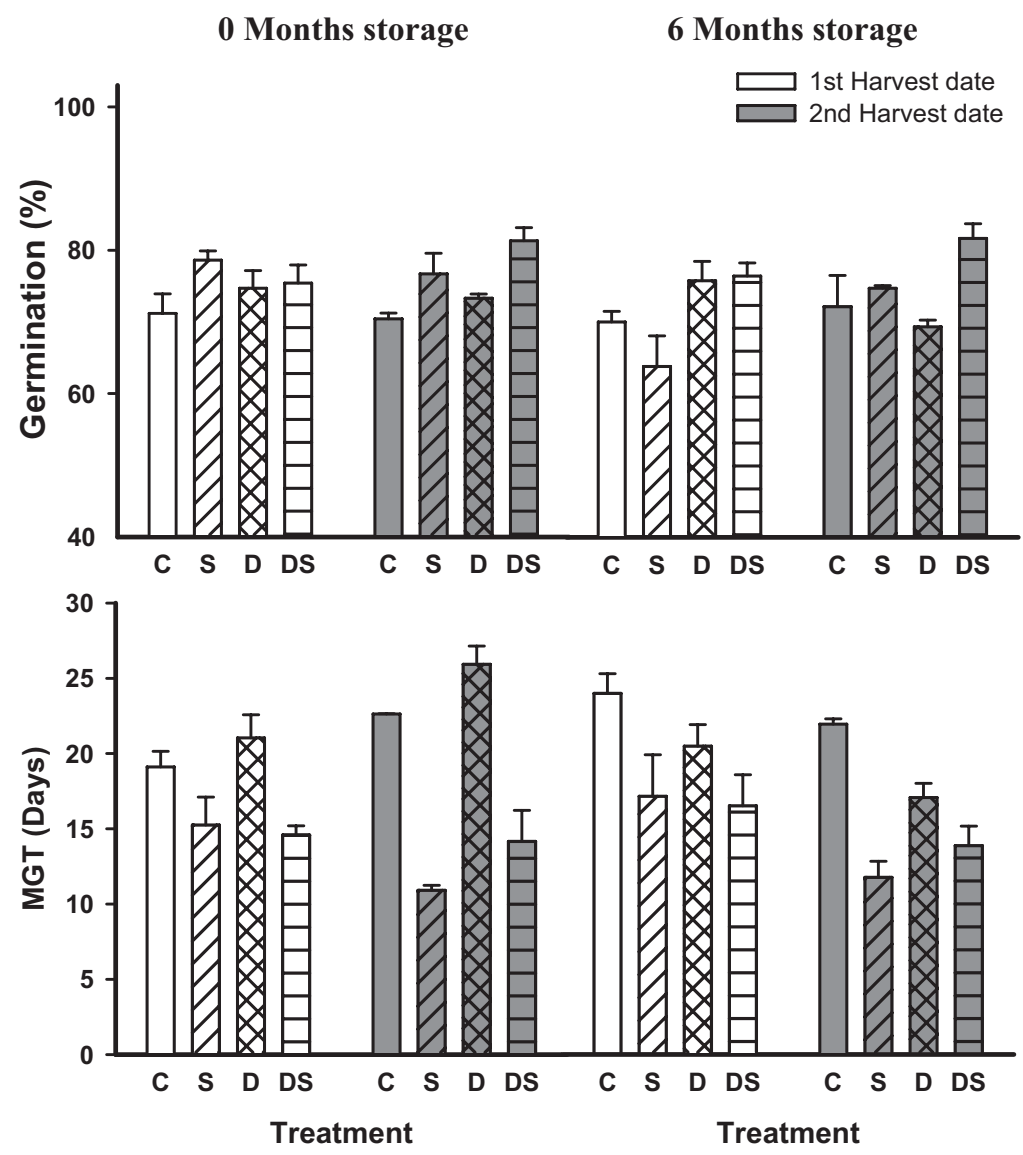

Figure 1. Effects of control (C), soaking (S), drying (D) and drying in combination with soaking (DS) treatments on acorn germination and MGT. Vertical lines are standard errors (one too small to be visible).

\subsection{2. $M G T$}

The soaked acorns germinated significantly faster than those given other treatments. Storage, harvest date and the interactions of these treatments with soaking also significantly affected MGT (Tab. II). In contrast, drying significantly delayed germination, but subsequent soaking reduced MGT, reversing the effect of previous drying.

After harvesting on the first date, the soaked acorns and those that were soaked after drying germinated faster (both 15 days) than the controls (19 days) and the acorns that were dried only (21 days) (Fig. 1). The trend was the same in the acorns harvested on the second date, although the soaked acorns germinated quicker (11 days) than those that were soaked after drying ( 14 days).

Acorns germinated significantly slower after six months storage, but the effect varied with pretreatment applied before storage. The effect of storage was significant for the acorns that had been soaked before storage. Acorns harvested on the second date germinated significantly faster after storage than those harvested on the first date. The effect of soaking on poststorage MGT was the same as that described for the non-stored acorns, but treatment differences were smaller.

\subsubsection{Experiment 2: seedling emergence and growth in nursery}

The effect of seed pretreatment on seedling emergence was almost identical each year (Tab. III). The acorns that had been dried and soaked resulted in 86\% (2005) or 87\% (2006) emergence compared with $71 \%$ (both years) for those given the standard treatment (acorns dried for storage). As expected, drying and soaking had no significant effect on seedling density since acorns given the latter treatment were sown at lower rates than those given the standard treatment.

Root collar diameter was significantly increased from $4.07 \mathrm{~mm}$ in the seedlings derived from standard-treated acorns to $4.25 \mathrm{~mm}$ in those derived from the DS acorns, but plant height was not affected significantly (Tab. III). In 2006, the proportion of plants with heights greater than $20 \mathrm{~cm}$ was significantly increased from $69 \%$ in those derived from standardtreated acorns to $86 \%$ in those derived from the DS acorns. In addition, the seedlings derived from the DS acorns had greater dry weights (2.03 g vs. $1.66 \mathrm{~g})$ and had higher RGP (27 vs. 18 new roots) than those derived from the standard-treated acorns. 
Table III. Seedling emergence, speed of emergence, plant density, morphological characteristics and root growth potential in plants derived from acorns given standard or drying and soaking treatments before storage. Means for plants derived from the soaked acorns that are significantly different from the standard treatment $(p<0.05)$ are indicated $\left(^{*}\right)$.

\begin{tabular}{|c|c|c|c|c|}
\hline & \multicolumn{2}{|c|}{$2005^{1}$} & \multicolumn{2}{|c|}{$2006^{2}$} \\
\hline & Standard & Soaked & Standard & Soaked \\
\hline Emergence (\%) & 70.8 & $86.7^{*}$ & 71.2 & $85.7^{*}$ \\
\hline Speed of emergence ${ }^{3}$ & $\mathrm{~N} / \mathrm{A}$ & $\mathrm{N} / \mathrm{A}$ & 23 & $42^{*}$ \\
\hline Plant density (number $/ \mathrm{m}^{2}$ ) & 181 & 196 & 142.4 & 149.9 \\
\hline Diameter (mm) & 4.18 & 4.38 & 4.07 & $4.25^{*}$ \\
\hline Height $(\mathrm{cm})$ & 24.8 & 26.2 & 25.3 & 26.9 \\
\hline Proportion $>20 \mathrm{~cm}(\%)$ & 70 & 75 & 69 & $86^{*}$ \\
\hline Shoot dry weight (g) & 1.66 & $2.03^{*}$ & 1.70 & 1.82 \\
\hline Root dry weight (g) & 7.00 & 8.53 & 4.44 & 4.47 \\
\hline RGP & N/A & N/A & 18.0 & $26.6^{*}$ \\
\hline
\end{tabular}

${ }^{1}$ Based on four replications of 40 seedlings each per treatment.

${ }^{2}$ Based on nine replications of 20 seedlings each per treatment, except for the RGP data which were based on 30 replications of three seedlings each per treatment.

${ }^{3}$ Percentage of seedlings that had germinated on the first observation date (17th June)

\section{DISCUSSION}

\subsection{Laboratory experiment}

The results of this study showed that soaking improved both germination percentage and germination speed in both the non-dried acorns (that had a high initial MC of 46-48\%) and those that were dried back (40-42\% MC) before soaking. Özbingöl and O'Reilly (2005) reported similar results, but they were unable to establish whether soaking or the increase in seed MC elicited this response. In this study, freshly harvested acorns that had a high initial MC were soaked, but this had no effect on their MC. Therefore, the beneficial effect of soaking on germination was probably through a softening of the pericarp and/or a leaching of substances that inhibit germination, rather than through a MC-mediated response. Water can leach inhibitors, such as ABA, from seeds (Black, 1992). A reduction in ABA levels is thought to increase cell wall extensibility (Finch-Savage et al., 1992) thus allowing radicle emergence. The increase in turgor pressure caused by imbibing weakens tissues, causing cell wall relaxation, facilitating this process (Schopfer and Plachy, 1985). This suggests that soaking helps to overcome mechanical dormancy in oak acorns. The beneficial effect of the soaking treatment was maintained during the 6 months of storage at $-3{ }^{\circ} \mathrm{C}$.

Another potential barrier to germination is lack of sufficient water within the acorn (Pammenter and Berjak, 1997). Newly shed recalcitrant seeds are metabolically active and undergo germinative processes that require water. Thus, acorns with high MC, regardless of how this was achieved, would have had more water available immediately for germination to proceed. Other studies have shown that acorn MC during storage affected germination after storage (Gosling, 1989; Finch-Savage et al., 1992; Suszka et al., 1996). Suszka (Suszka et al., 1996) found that pedunculate oak seeds had higher germination after 100 days storage at $44 \% \mathrm{MC}$ than those held at MC levels from 23 to $37 \%$.

Harvest date significantly affected both germination percentage and MGT, but the effect was most pronounced in combination with drying and soaking. This suggests that the level of maturity influenced the response. There was a small harvest date difference in acorn MC (mean of $48 \%$ and $46 \%$ for acorns harvested on the first and second dates, respectively). Immature acorns are green but turn brown as they ripen (FinchSavage et al., 1996). The pericarps of the acorns harvested on the first date were partly green whereas those harvested on the second date were entirely brown. Acorns collected on the second date also germinated more quickly than those collected on the first date (Fig. 1), probably because they were more mature. Changes associated with the maturation process during seed development, such as a decrease in the MC of the cotyledons and an increase in starch content (Finch-Savage et al., 1992) may have influenced germination after harvesting. Acorns become more tolerant to desiccation stress during this period (Finch-Savage et al., 1992). In addition, ABA concentrations are highest in immature acorns, with levels declining as the acorns mature; germination potential usually increases during this period (Finch-Savage and Clay, 1994). Acorn ABA levels were not evaluated in this study, however.

Drying appeared to have little effect on the germination of the non-stored acorns, but improved germination of acorns that had been stored. However, drying alone was effective in improving the storability of acorns harvested on the first date, but the effect was evident only in combination with soaking for acorns harvested on second date. In addition, drying reduced germination speed, except when followed by soaking. Since the acorns were dried to 40-42\% MC (a MC level which does not cause damage (Suszka and Tylkowski, 1980)), it is likely that the lower availability of water probably delayed germination after storage. Furthermore, water may have been able to penetrate the pericarp more readily after drying. This may also explain why the combined effect of drying and soaking was generally more effective than either treatment applied alone. However, mild desiccation stress may result in an increase in ABA concentrations; this can delay germination on subsequent imbibition (Finch-Savage, 1992).

Soaking improved post-storage germination in this study, but this method may be less effective in improving storability for longer than 6 months. In fact these treatments (or treatment combinations) might reduce long-term storability since acorns stored at high MC are more prone to fungal infection and it has been shown that mycelium of Ciboria batschiana can grow even at $-3{ }^{\circ} \mathrm{C}$ (Shroeder, 2002). The effect of long-term (> 6 months) storage on germination was not evaluated in this study.

The results of this study also showed that soaking acorns before storage improved germination and this advantage was maintained during storage for those that were dried and then soaked. Unfortunately, there was not a sufficient quantity of acorns available in this study to evaluate the benefit of soaking after storage (due to the malfunction of one freezer). However, 
the results of a separate experiment, using two other lots, revealed that acorns that had been dried for storage and then soaked after storage had similar germination to those that had been dried and soaked for storage (unpublished data on file).

\subsubsection{Nursery experiment}

The acorns that were dried and then soaked before storage resulted in significantly better emergence in the nursery than those that had been dried back only (standard method), consistent with the results from the laboratory experiments in this (Fig. 1) and an earlier (Özbingöl and O'Reilly, 2005) study. Therefore, fewer treated acorns are needed to achieve the same density of plants using the DS treatment than the standard one. There was evidence that the DS treatment also improved plant quality and yields.

A higher proportion of the seedlings resulting from acorns given the DS treatment exceeded $20 \mathrm{~cm}$ height, suggesting that the yield of usable plants might also be higher than in seedlings derived from the standard-treated ones. Oak is normally grown for two years to $>40 \mathrm{~cm}$ height in Irish nurseries (Joyce, 1998). It is likely that a higher proportion of the seedlings in the beds sown with the DS-treated acorns will have reached this target in 2007 than in those sown with the standard treatment, but this was not evaluated.

The root collar diameter and the RGP of seedlings derived from the DS-treated acorns were significantly greater than those given the standard treatment. Root collar diameter may be the best and most consistent morphological indicator of hardwood seedling field performance potential (Wilson and Jacobs, 2006). RGP may be the most useful indicator of plant vitality (Ritchie, 1984). RGP was positively correlated with field growth and survival in seedlings of holm oak (Quercus ilex L.) (Pardos et al., 2003), sessile oak (Quercus petrea Matt.) (Mortazavi et al., 2004) and with the survival of pedunculate oak after cold storage (Lindqvist and Asp, 2002). It appears that soaking of acorns prior to freezing storage could potentially increase the yield and quality of oak seedlings in the nursery.

\section{CONCLUSIONS}

The main finding of this study is that both drying and soaking acorns increases germination percentage and speed both before and after storage at $-3{ }^{\circ} \mathrm{C}$. Harvest date in October had a small effect on this outcome, although acorns that were harvested on the second date performed better in response to drying, soaking and storage treatments than those harvested on the first date.

The second experiment in the nursery showed that acorns that were dried and soaked before storage resulted in higher and faster seedling emergence than acorns that were given the standard treatment (dried before storage). A high proportion of the seedlings were taller than $20 \mathrm{~cm}$ and the seedling yield and RGP was higher for plants lifted from plots that were sown with dried and soaked acorns than in those sown with standardtreated acorns.

\section{REFERENCES}

Aldhous J.R. and Mason W.L., 1994. Forest nursery practice, HMSO, London, $268 \mathrm{p}$.

Black M., 1992. Involvement of ABA in the physiology of developing and mature seeds. In: Davies W.J. and Jones H. (Eds.), Abscisic acid: physiology and biochemistry. Bios Scientific Publishers Oxford, pp. 99-124.

Bonner F.T. and Vozzo J.A., 1987. Seed biology and technology of Quercus New Orleans, Louisiana, USDA Forest Service, 21.

Finch-Savage W.E., 1992. Embryo water status and survival in the recalcitrant species Quercus robur L.: Evidence for critical moisture content. J. Exp. Bot. 43: 663-669.

Finch-Savage W.E. and Clay H.A., 1994. Evidence that ethylene, light and abscissic acid interact to inhibit germination in the recalcitrant seeds of Quercus robur L. J. Exp. Bot. 45: 1295-1299.

Finch-Savage W.E., Clay, H.A., and Blake P.S., Browning G., 1992. Seed development in the recalcitrant species Quercus robur L.: Water status and endogenous abscissic acid levels. J. Exp. Bot. 43: 671-679.

Finch-Savage W.E., Blake P.S., and Clay H.A., 1996. Desiccation stress in recalcitrant Quercus robur L. seeds results in lipid peroxidation and increased synthesis of jasmonates and abscissic acid. J. Exp. Bot. 47: 661-667.

Gordon A.G., 1992. Seed manual for forest trees, HMSO, London, 132 p.

Gosling P.G., 1989. The effect of drying Quercus robur L. acorns to different moisture contents, followed by storage, either with or without imbibition. Forestry. 62: 41-50.

Jensen M., 2002. Changes in percentage and speed of root and shoot germination in Quercus robur L. after a control moisture content chilling treatment. In: Proceedings of the conference on Tree Seeds, Chania, Crete, Greece.

Jones S.K. and Gosling P.G., 1994. "Target moisture content" prechill overcomes the dormancy of temperate conifer seeds. New For. 8: 309-321.

Joyce P.M., 1998. Growing broadleaves: silvicultural guidelines for ash, sycamore, wild cherry, beech and oak in Ireland, COFORD, Dublin, $144 \mathrm{p}$.

Lindqvist H. and Asp H., 2002. Effects of lifting date and storage time on changes in carbohydrate content and photosynthetic efficiency in three deciduous species. J Hortic. Sci. Biotech. 77: 346-354.

Mortazavi M., O’ Reilly C., and Keane M., 2004. Stress resistance levels change little during dormancy in ash, oak and sycamore seedlings. New For. 28: 89-108.

Özbingöl N. and O'Reilly C., 2005. Increasing acorn moisture content followed by freezing-storage enhances germination in pedunculate oak. Forestry 78: 73-81.

Pammenter N.W. and Berjak P., 1997. A review of recalcitrant seed physiology in relation to desiccation tolerance mechanisms. Seed Sci. Res 9: 13-37.

Pardos M., Royo A., Gil L., and Pardos J.A., 2003. Effect of nursery location and outplanting date on field performance of Pinus halepensis and Quercus ilex seedlings. Forestry 76: 67-81.

Poulsen K.M., 1992. Seed storage physiology of recalcitrant acorns from Pedunculate Oak (Quercus robur L.) and orthodox nuts from the European beech (Fagus sylvatica L.). Ph .D. thesis, Royal Veterinary and Agricultural University, Copenhagen.

Ritchie G.A., 1984. Assessing seedling quality. In: Duryea M.L. and Landis T.D. (Eds.), Forest nursery manual: Production of bareroot seedlings. Corvallis, Oregan, pp. 243-259.

SAS Inc, 1989. SAS/Star ${ }^{\circledR}$ Users guide, Cary, NC, 943 p.

Schopfer P. and Plachy C., 1985. Control of seed germination by abscissic acid. III. Effect on embryo growth potential (minimum turgor pressure) and growth coefficient (cell wall extensibility) in Brassica napus L. Plant Physiol 77: 676-686.

Shroeder T., 2002. On the geographic variation of Ciboria batschiana (Zopf) Buchwald, the main pathogenic fungus on acorn of Quercus robur and Q. petraea in Europe. Dendrobiolgy 47: 13-19.

Suszka B., Muller C., and Bonnet-Masimbert M., 1996. Seeds of forest broadleaves - from harvest to sowing, Trad. from French by Gordon A., INRA éd., Paris, 334 p.

Suszka B. and Tylkowski T., 1980. Storage of acorns of the English oak (Quercus robur L.) over 1-5 winters. Arboretum Körnikie 25: 199288.

Wilson B.C. and Jacobs D.F., 2006. Quality assessment of temperate zone deciduous hardwood seedlings. New For 31: 417-433. 